\title{
Laboratory Work-Up of Chronic B-Cell Lymphoid Malignancies - A Value-Based Approach
}

\author{
Department of Laboratory Medicine and \\ Pathology, Mayo Clinic Rochester MN \\ Correspondence: \\ jevremovic.dragan@mayo.edu \\ Tel.: + 15072930295 \\ Fax.: + 15072845115
}

Min Shi, Linda Dao, Dragan Jevremovic

Received: 26 September 2018

Accepted: 3 January 2019

Key Words: Lymphoma • Pathology • Prognosis.

\begin{abstract}
The aim of study was to summarize recent developments in laboratory work-up of lymphomas and discuss their clinical relevance. Diagnosis of lymphoma requires tissue biopsy with adequate work-up by pathologists. Recent developments in laboratory testing have raised the bar for establishing the diagnosis: more and more testing seems to be required, while the lines between research and clinical practice are being blurred. Academic medical practice is designed to push boundaries and test new hypotheses, which eventually result in improved patient care. Ability to (relatively) cheaply screen for multiple genomic abnormalities using new technologies is luring. Often, however, no change in patient management is pursued based on these results. It is therefore useful to review which testing is truly necessary from the patient's point of view. Conclusions. The laboratory work-up of lymphomas in a regular clinical practice requires relatively few tests. Many new tests have prognostic value, but do not necessarily contribute to the patient management.
\end{abstract}

\section{Introduction}

Malignant lymphomas are neoplasms of mature lymphocytes, involving lymph nodes as well other hematopoietic (bone marrow, spleen) and non-hematopoietic tissues (gastrointestinal tract, skin, etc.). In the United States, lymphomas account for approximately $4-5 \%$ of all new cases of malignant diseases. About $90 \%$ of all lymphomas are of B-cell lineage.

The new WHO classification of lymphoid malignancies continued in the steps of previous versions by keeping the multifactorial approach in disease definition (1). Clinical features are represented by aggressiveness in presentation and localization. Morphologic findings include cell size and shape, presence and distribution of nucleoli, quality and quantity of cytoplasm, and the pattern of growth. Immunophenotype of the cells is critical in assigning lineage and differentiation pattern, linking the malignant cells to their normal counterparts. Cytogenetic findings are sometimes used as disease-defining events, in cases of the recurrent translocations (involving MYC, CYCLIN D1, or BCL2 loci, for example), in the right clinical and morphologic context. Finally, detection of molecular abnormalities includes clonality assays for immunoglobulin or T-cell receptor gene rearrangements, and a plethora of novel point mutations. The newly described mutations are most commonly discussed as prognostic variables, with very few of them approaching the level of disease-defining events (MYD88 L265P for lymphoplasma- 
cytic lymphoma; BRAF V600E for hairy cell leukemia).

When ordering laboratory test, such as gene mutation profile for lymphoma, it is important to keep in mind the ultimate purpose, whether it is to confirm/establish a diagnosis, identify a prognostically important marker, or to guide decision on therapy choice and duration. It is also necessary to be clear whether the testing is done in the routine clinical practice, well-controlled clinical trial environment, or as a purely research endeavor. In reality, these different scenarios are often intermingled, which leads to a lot of unnecessary testing, resulting in increased burden for the laboratory operations and increased health care costs.

In this review, we will assess the current knowledge and utility of laboratory testing in the most common B-cell lymphomas.

\section{Chronic Lymphocytic Leukemia/ Small Lymphocytic Lymphoma}

Chronic lymphocytic leukemia/small lymphocytic lymphoma (CLL/SLL) is the most common B-cell lymphoproliferative disorder, accounting for almost $20 \%$ of all NHL cases (2). Most cases are diagnostically straightforward: high lymphocyte count in the peripheral blood (need $\geq 5 \times 10^{9}$ clonal B-cells/L for the diagnosis of CLL), typical morphology with small lymphocyte size and "checkered" chromatin, and typical immunophenotype showing dim CD20 expression and co-expression of CD5, CD23, and CD200. Because of its high prevalence, and the ease of obtaining the specimen from peripheral blood, CLL/SLL is probably the most studied hematologic disease. There is an "overabundance" of prognostic markers available. For example, serum LDH, beta2microglobulin, thymidine kinase, vitamin $\mathrm{D}$, circulating CD26, BAFF, and vitamin $\mathrm{D}$ are all predictive of the behavior of the disease (3-5). In particular, LDH level, as a correlate to the cell turnover, is predictive of Richter's transformation (6). Similarly, looking at malignant cell morphology and phenotype, there are numerous variables of poor prognosis, including CD38 expression in $\geq 30 \%$ of cells, ZAP70 expression in $\geq 20$ $30 \%$ of cells, CD $49 \mathrm{~d}$ expression in $\geq 30-45 \%$ of cells, and high proliferative rate measured by DNA staining or mitotic activity $(7,8)$. RNA-based assays can also be employed in prognostication of CLL/SLL. For example RNA levels of ZAP70 and CD38 correlate with expression of these markers and poor prognosis. In addition, gene expression profiling can identify microRNA expression signatures which are associated with more aggressive disease course (9). Detection of chromosomal abnormalities is a mainstay of prognostic factor determination in CLL/ SLL, with del(17p), del(11q), trisomy 12 and complex karyotype ( $\geq 3$ clonal abnormalities) typically associated with poor outcome $(10,11)$. Single gene sequencing assays are employed to determine the level of somatic hypermutation $(\mathrm{IgVH} ;>2 \%$ difference from the germline is associated with better prognosis) (12), to "stereotype" immunoglobulin gene into prognostic subsets (13), and to assess the presence of TP53 inactivating mutations (14-16). In addition, recently a number of additional genes with prognostic significance have been identified. For example, mutations in NOTCH1 are associated with a more aggressive clinical course, including higher likelihood of Richter's transformation and diminished responsiveness to rituximab (17). SF3B1 and BIRC3 mutations are similarly associated with a more aggressive disease (18).

As the number of potential prognostic factors for CLL/SLL is ever-increasing, it is important to try to integrate them into an actionable model for patients requiring treatment (19). A number of models have been proposed throughout the years, starting with Binet and Rai staging schemes from 
1970s. The most recent prognostic models include staging information, clinical and laboratory findings, and a limited number of variables. International Prognostic Index (CLL-IPI) was developed by the International CLL Working Group in 2016 (4). It includes patient age, Rai/Binet stage, beta2microglobulin level, IgVH status, and $17 \mathrm{p} /$ TP53 abnormalities. In fact, the prognostic model is weighed, so that $17 \mathrm{p} / \mathrm{TP} 53$ abnormalities contribute the most to the overall prognostic score, see Tables 1 and 2.

Table 1. CLL-IPI Score Sheet (4)

\begin{tabular}{ll}
\hline Parameter & Points \\
\hline FISH 17p- or TP53 mutation & 4 \\
\hline IGVH unmutated & 2 \\
\hline Beta-2-microglobulin $>3.5 \mathrm{mg} / \mathrm{dL}$ & 2 \\
\hline Rai stage I-IV/Binet B-C & 1 \\
\hline Age $>60$ years & 1 \\
\hline Total max & 10 \\
\hline
\end{tabular}

CLL-IPI=Chronic lymphocytic leukemia - International Prognostic Index; FISH=Fluorescent in-situ hybridization; TP53; $\mathrm{IGVH}=$ Immunoglobulin heavy chain variable region.

Table 2. Treatment-Free Survival in CLL/SLL by CLLIPI Score.

\begin{tabular}{lll}
\hline Points & Risk category & Treatment $(\%)^{*}$ \\
\hline $0-1$ & Minimal & 78 \\
\hline $2-3$ & Low & 54 \\
\hline $4-6$ & Intermediate & 32 \\
\hline $7-10$ & High & 0 \\
\hline
\end{tabular}

CLL/SLL= Chronic lymphocytic leukemia/small lymphocytic lymphoma; CLL-IPI=Chronic lymphocytic leukemia - International Prognostic Index; "5 year treatment - free survival, Mayo Clinic, Rochester, unpublished data.

Based on this score, patients are stratified into the prognostic subgroups with clear difference in survival. While the mutation profiling is useful in research and clinical study settings, at this point it appears that for a regular clinical practice parameters covered in CLL-IPI would suffice for the management of patients requiring treatment, to select the most appropriate treatment combination.
From pathology work-up perspective, that would limit the evaluation of CLL/SLL cells to IgVH, FISH for $17 \mathrm{p}$ deletion, and TP53 mutation analysis.

Patients who have undergone treatment, and are in remission by standard techniques (CT scan-negative, blood lymphocytes $<4000 / \mathrm{microL}$, bone marrow lymphocytes $<30 \%$ ) could undergo minimal residual disease (MRD) testing by flow cytometry immunophenotyping or molecular analysis (PCR, next generation sequencing) (19). The detection of the MRD is associated with shorter progression-free and overall survival. Patients in clinical trials are regularly tested for the presence of MRD. Outside clinical trials MRD testing is sporadic and should be restricted to potentially curative treatments.

\section{Follicular Lymphoma}

Follicular lymphoma (FL) is a neoplasm of follicle center (germinal center) B-cells, which accounts for about $20 \%$ of all lymphomas (20). Pathologic evaluation of FL is relatively straight forward and consists of establishing (I) neoplastic nature of the lymphocytes and (II) their follicular origin. A simple hematoxylin/eosin stain is often enough to establish both of these, when a lymph node is completely effaced by uniform population of follicles without polarity. However, immunostains are very helpful for evaluation of less obvious cases, particularly needle biopsy specimens. BCL2 expression on germinal center cells (defined by CD10 and/or BCL6) is diagnostic of follicular lymphoma. In addition, BCL2 staining is necessary for the detection of in-situ follicular neoplasia. Overexpression of BCL2 is a result of a IGH/BCL2 translocation $\mathrm{t}(14 ; 18)$ (q32; 21 ); however FISH for this abnormality is rarely needed in general clinical practice if adequate evaluation by immunohistochemistry is done. 
Prognostically, the most important factors are grade ( $1 / 2$ vs. $3 \mathrm{~A}$ vs. $3 \mathrm{~B}$; established by counting the number of centroblasts per high power field) and clinical stage, usually defined by FLIPI scores. FLIPI (Follicular Lymphoma International Prognostic Index) and FLIPI2 scores integrate several clinical and laboratory parameters, including age, $\mathrm{LDH}$ level, size of the largest lymph node, bone marrow involvement, and hemoglobin level $(21,22)$. Therefore, routine work-up of follicular lymphomas does not require sophisticated molecular or cytogenetic testing. The two exceptions are cases of pediatric-type follicular lymphoma and large B cell lymphoma with IRF4 rearrangement which may have follicular architecture. Pediatric-type FL is usually found in children and young adults, in the head and neck region (23). These tumors show high grade morphology (FL grade $3 \mathrm{~A}$ or $3 \mathrm{~B}$ ) and high proliferation rate but lack BCL2 staining and by definition do not have rearrangements of BCL2, BCL6 or IRF4 loci by FISH. On the other hand, they often have deletion of 1 p36 region or mutations in TNFRSF 14 gene (24). Large B-cell lymphoma with IRF4 rearrangement has a similar epidemiology and localization to pediatric-type follicular lymphoma, and, as its name suggests, is defined by the translocations involving IRF4 locus, most commonly juxtaposed to IGH locus (25). Both pediatric type FL and large B-cell lymphoma with IRF4 rearrangement are relatively indolent diseases, the former rarely requiring systemic therapy. If there is a high level of suspicion for one of these 2 types of follicular lymphomas (young patient, high grade follicular morphology), it is prudent to perform FISH for BCL2, BCL6 and IRF4 rearrangements.

There are numerous studies showing a potential for different gene mutations to be helpful in the prognosis of FL, including $\mathrm{m} 7$-FLIPI panel, and p53 mutations (26, 27). However, usefulness of these tests is not yet widely accepted, and more studies are needed before they can be recommended for a routine clinical practice.

\section{Mantle Cell Lymphoma}

Mantle cell lymphoma (MCL) is an aggressive neoplasm of small mature B-cells, characterized by CCND1/IGH translocation and the resulting cyclin D1 overexpression (28). The diagnosis of a typical mantle cell lymphoma is usually straight forward: the involved lymph node is effaced by a monotonous infiltrate of small lymphocytes with hyperchromatic irregular nuclei. The typical phenotype of MCL is CD20 bright $\mathrm{CD}^{+} \mathrm{CD} 23$ CD200. This phenotype can be overlapping with that of CLL/SLL, as well as marginal zone lymphoma or lymphoplasmacytic lymphoma. Therefore it is necessary to prove either CCND1/IGH translocation, or uniform nuclear expression of cyclin D1, but usually there is no need to do both. It is, however, necessary to correlate the morphology and FISH findings with the immunophenotype, as cyclin D1 can frequently be seen overexpressed in plasma cell neoplasms (with CCND1/IGH translocation) and hairy cell leukemia (without CCND1/IGH translocation). Lymph nodes with preserved follicular architecture may contain in-situ mantle cell neoplasia, which is a rare indolent disorder that can be recognized only when staining slides for cyclin D1.

Similar to CLL/SLL and FL, prognosis of MCL is guided by staging. Mantle cell lymphoma international prognostic index (MIPI) is based on patient age, ECOG performance status, $\mathrm{LDH}$ level and the WBC count in the peripheral blood (29). From pathology perspective, there are three important parameters to consider. First, it is necessary to assess morphology to determine if there is a pleomorphic or blastic appearance of the cells, both of which are associated with a more aggressive disease. Second, 
expression of SOX11 should be evaluated. Classical, nodal-based MCL is positive for SOX11, and in rare cases of cyclin D1-negative MCL, SOX11 is a key diagnostic marker $(30,31)$. In contrast, SOX11-negative mantle cell lymphoma is typically an indolent disease, involving peripheral blood, bone marrow and spleen, and sparing the lymph nodes (32-34). Finally, it is important to assess proliferative activity, by Ki67 immunostain, since there is a correlation between proliferative activity and poor prognosis. For simplification, a cutoff of $30 \%$ has been validated as a useful addition to MIPI score (35), but other cutoffs have also been used. Overexpression of TP53 is also associated with a more aggressive disease (36). There is a potential value of additional cytogenetic and molecular testing in MCL, mostly to determine predictors of poor prognosis, such as $9 p$ and $17 p$ deletions. In addition, TP53 mutations are also predictive of aggressive clinical course, and even the indolent form of MCL may turn into a very aggressive disease if TP53 mutations are acquired. Other potential genes of interest include CCND1 and BIRC3. Mutations in these 2 genes have been associated with ibrutinib resistance $(37,38)$, though it is still unclear whether finding these mutations requires a different clinical approach.

\section{Lymphoplasmacytic Lymphoma}

Lymphoplasmacytic lymphoma (LPL) is a neoplasm of small lymphocytes, plasmacytoid lymphocytes and mature plasma cells, all derived from a single B-cell clone (39). It usually affects bone marrow, and often spleen and lymph nodes as well. Most cases are associated with increased IgM production, leading to the clinical syndrome of Waldenström macroglobulinemia (WM). The distinction between LPL and marginal zone lymphoma (MZL) with plasmacytic differentiation is somewhat arbitrary as no definitive morphologic, immunophenotypic or genetic markers are present. Recently identified mutation in the adaptor protein MYD88 (L265P) is found in $>90 \%$ of LPL cases, but can also be seen in cases of MZL and DLBCL (particularly of immunoprivileged sites) (40). Therefore, molecular testing for this mutation is helpful, but the positive result has to be interpreted in the context of the morphologic findings. Presence of MYD88 L265P mutation is associated with a good response to ibrutinib therapy; however about $30 \%$ of LPL also contains CXCR4 mutations which confer resistance to ibrutinib (41). LPL is usually an indolent disease, treated based on the disease stage and other significant pathologic findings to determine prognosis or therapy are established. In fact, the most important part of the pathologic evaluation is to exclude multiple myeloma (MM) from the differential diagnosis, as the treatment approach is completely different between MM and LPL. Plasma cells in LPL are usually positive for CD19 and CD45 and negative for CD56 and cyclin $\mathrm{D} 1$, in contrast to plasma cells in MM. In addition, MYD88 L265P mutation has not been identified in MM.

\section{Multiple Myeloma}

Multiple myeloma (MM, plasma cell myeloma) is a neoplasm of mature plasma cells $(\geq 10 \%)$ involving the bone marrow, and is usually associated with the presence of monoclonal (M) protein in the serum and urine. The diagnostic criteria for the active MM have been updated recently (42), to include so-called biomarkers of malignancy ( $\geq 60 \%$ clonal plasma cells in the bone marrow, free light chain ration of $\geq 100$ and $>1$ focal lesion on MRI); any one of these features, as well as previously recognized "CRAB" findings, excludes the possibility of smoldering multiple myeloma (SMM) and warrants treatment. The quantification of plasma cells is crucial in establishing the 
diagnosis of MM. This is best done by morphology (on the aspirate slide), and/or by immunohistochemical stain for CD138 or MUM (on the biopsy slide). Flow cytometry is not a reliable method of quantifying plasma cells in the diagnostic specimen for MM. Plasma cells are usually underestimated by flow cytometry immunophenotyping, as they tend to be associated with the lipid phase of the bone marrow aspirate, which gets lost during the staining and washing steps in sample preparation. On the other hand, flow cytometry is an excellent method for evaluating the phenotype: plasma cells in multiple myeloma are cytoplasmic light chain restricted (or rarely negative), usually dim for CD38, negative for CD19 and CD45, and often positive for CD56 and CD117.

Prognostically, MM is stratified into a high risk and standard risk disease. The criteria for high risk include presence of $t(4 ; 14), t(14 ; 16)$, $\mathrm{t}(14 ; 20)$, del(17p), add(1p) and TP53 mutations. In addition, high stage disease, high risk gene expression profiling signature and high plasma cell proliferative rate are also risk factors which fulfill criteria for the high risk MM (43). In practice, very few institutions employ all of the prognostic markers, but FISH studies remain essential. Numerous point mutations have been found in multiple genes in MM samples (44). The usefulness of gene mutation screens is not yet well established, and they are mostly utilized in relapsed/refractory disease for which innovative treatment options are explored. The exception may be detection of biallelic TP53 mutations/17p deletions, which are associated with a particularly aggressive disease $(45,46)$.

Similarly to CLL/SLL, MM patients who have undergone therapy and are in complete remission may benefit from performing MRD study on the bone marrow aspirate, by flow cytometry or molecular techniques (47). MRD status is a strong predictor of survival, but at this point it is not used to guide treatment adjustment.

\section{Diffuse Large B-Cell Lymphoma and Aggressive B-Cell Neoplasms}

Diffuse large B-cell lymphoma (DLBCL) is a neoplasm of medium-to-large B-cells with a diffuse growth pattern. The size of nuclei has to be at least the same or larger than size of macrophage nuclei, or twice the size of the nuclei of small lymphocytes (48). DLBCL accounts for about $30 \%$ of all non-Hodgkin lymphomas, and it is considered an intermediate grade disorder, which requires treatment. Historically, the term DLBCL has been an all-encompassing "waste-basket" for any B-neoplasm with large cells. Over time, more specific entities have differentiated into separate diseases. For example, the latest WHO classification recognizes following separate entities: large B-cell lymphoma with IRF4 rearrangement, T-cell/histiocyte-rich large B-cell lymphoma, primary DLBCL of the CNS, primary cutaneous DLBCL, leg type, EBV-positive DLBCL, NOS, DLBCL associated with chronic inflammation, lymphomatoid granulomatosis grade 3, primary mediastinal (thymic) large B-cell lymphoma, intravascular large B-cell lymphoma, ALKpositive large B-cell lymphoma, HHV8positive DLBCL, plasmablastic lymphoma, and primary effusion lymphoma (1). The remaining cases fulfilling diagnostic criteria for DLBCL are designated as DLBCL, not otherwise specified (NOS).

As with other lymphomas, the prognosis of DLBCL is primarily determined by clinical features and staging studies. Biologically, based on cell of origin/postulated normal counterpart, DLBCL cases can be divided into two groups: germinal center B cell type (GCB) and activated B-cell/post-germinal center type $(\mathrm{ABC})$. The two groups differ in their gene expression patterns, chromosomal abnormalities, recurrent mutations, and, to a certain extent, prognosis and therapy response. WHO classification of lymphoid neoplasms requires subtyping of DLBCL, 
NOS at diagnosis, by cell of origin. Originally, the cell of origin grouping was achieved by gene expression profiling (GEP) $(49,50)$. This was followed by development of multiple immunohistochemical algorithms which were able to match GEP classification in the majority of cases. The most commonly used is Hans algorithm (51), which requires staining of DLBCL cases with CD10, MUM1 and BCL6. CD10 and BCL6 staining indicate GBC type; MUM1 staining is associated with $\mathrm{ABC}$ type; the order of importance is CD10>MUM1>BCL6; 30\% staining is used as a cutoff. Although immunohistochemical staining for cell of origin lacks in reproducibility and accuracy, it is now widely used to classify DLBCL cases. Recently, the GEP platform for cell of origin classification has become commercially available (52), but the cost and logistics still prevent it from widespread use. Other important prognostic markers used in pathology workup of DLB$\mathrm{CL}$ include staining for CD5 (positive staining associated with a more aggressive disease (53)), BCL2, MYC (MYC and BCL2-double expressors have worse prognosis (54)), and, possibly, EBV (EBV positivity removes the case from DLBCL, NOS to EBV-positive DLBCL, with worse prognosis in older patients, and better in younger patients; therapeutic options may also differ based on the immunosuppression context). Numerous single gene mutations have been identified in DLBCL. Many of them are associated with $\mathrm{ABC}$ phenotype and constitutive activation of B-cell receptor and NFKB signaling pathway (55). While there is a potential use of the mutation panels in determining prognosis, their therapeutic value awaits results from ongoing clinical trials.

Burkitt lymphoma (BL) is an aggressive neoplasm of medium-size mature B-lymphocytes with blastic-appearing chromatin (56). It mainly affects children and young adults. Endemic BL is EBV-driven and limited to equatorial Africa and Papua New
Guinea. Sporadic BL is distributed worldwide, including Europe and USA, and is relatively rare (1-2\% of all lymphomas). Immunophenotype of $\mathrm{BL}$ is fairly typical: the cells have a mature B-phenotype (CD20-positive, light chain-restricted, TdT-negative), show germinal center B-cell differentiation (CD10 and BCL6-positive), and are also CD43-positive and BCL2-negative. A hallmark of BL is the presence of MYC rearrangements, usually in the form of MYC/IGH translocation $\mathrm{t}(14 ; 18)(\mathrm{q} 24 ; \mathrm{q} 32)$. A relatively small fraction of BL cases don't have MYC rearrangement by available techniques. Some of these cases likely have unusual breakpoints, not detectable by common FISH probes. Rare cases of $\mathrm{BL}$ have aberrations of $11 \mathrm{q}$ region instead (57). BL is a potentially curable disease with aggressive chemotherapy.

High grade B-cell lymphoma (HGBCL) with MYC and BCL2 and/or BCL6 abnormalities is a relatively new term designating an aggressive lymphoma occurring mostly in the elderly people (58). In the past 20 years there has been an increasing recognition of a subgroup of aggressive B-cell lymphomas which do not satisfy strict criteria for DLBCL of BL. It was subsequently discovered that many of these cases have two or even three major genetic events that are driving their behavior. Invariably, these neoplasms have MYC rearrangement, which can be paired with BCL2 and/or BCL6 rearrangement ("double or triple-hit lymphoma"). The behavior of these neoplasms is significantly more aggressive than that of DLBCL, and R-CHOP therapy is associated with short survival $(59,60)$. More aggressive therapeutic approaches are being tested in clinical trials. Importantly, the morphology of HGBCL with MYC and BCL2 and/ or BCL6 rearrangement can be blastoid/ Burkitt-like, large cell/DLBCL-like, or fall somewhere in between the two. Therefore, any case of DLBCL may contain these abnormalities, although having a germinal 


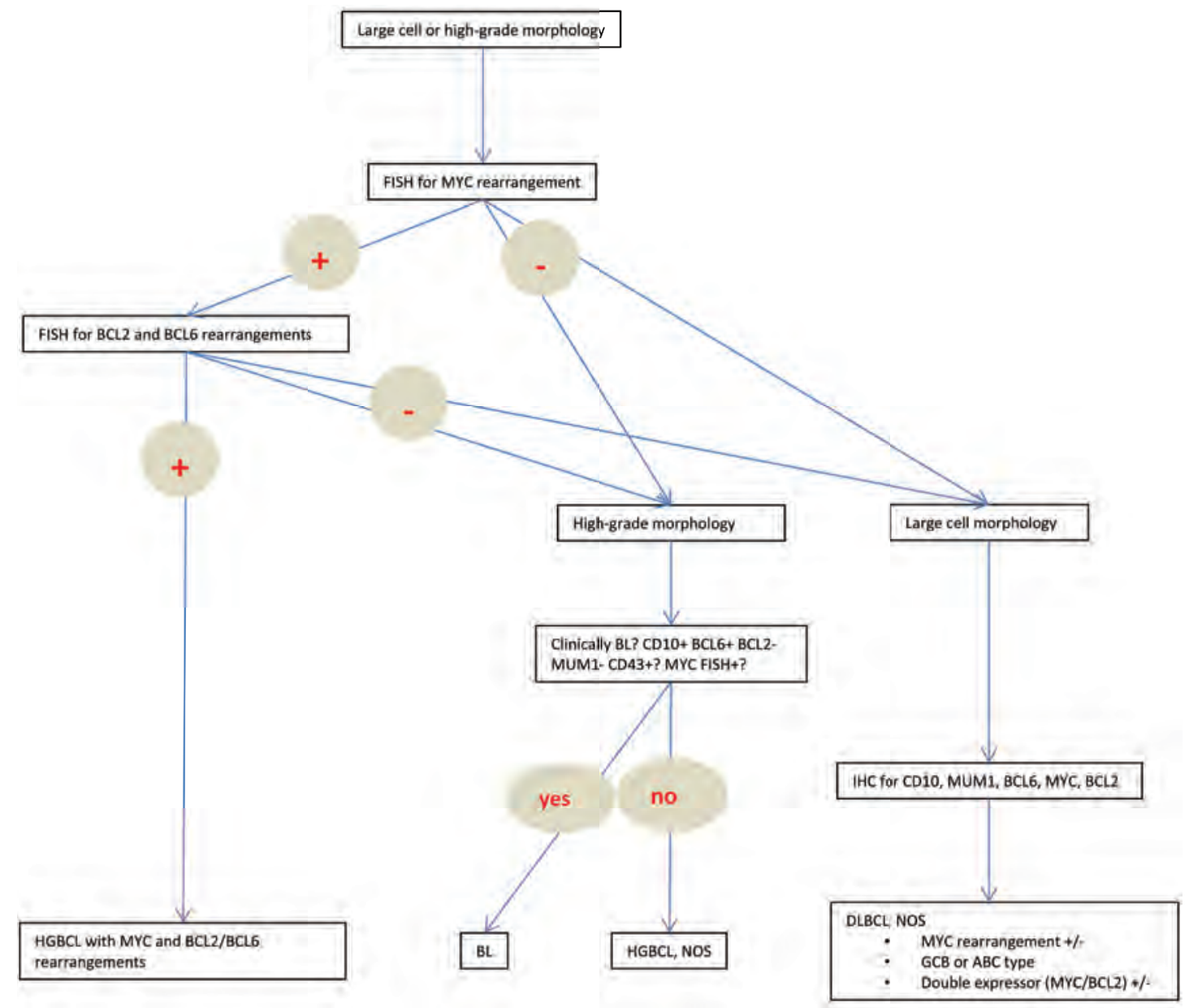

Figure 1. A Simplified Algorithm for the Work-Up of DLBCL and HGBCL.

center phenotype increases their likelihood. As a result of these findings, it is practically impossible to diagnose DLBCL without excluding the possibility of a "double or triplehit lymphoma" by FISH. An example of a rational approach to the pathology workup of DLBCL and high grade B-cell lymphomas is shown in Figure 1.

\section{Conclusion}

Application of new technologies has been exponentially increasing our knowledge of genetics and pathology of lymphomas. Clinical utility for many of these findings is lagging behind for several reasons. First and foremost, the rationale for ordering a test in a routine clinical practice has to be that the result will change the clinical approach (choice of therapy, frequency of follow-up). With still limited therapeutic options, the benefit for the patients from undergoing advanced genetic testing is questionable. In addition, there are limited resources available. Even large academic centers, which have testing infrastructure on-site, struggle to offer advanced genetic testing due to the fact that the reimbursement by insurance companies is, at best, inconsistent. This review summarizes the rational approach to pathology workup of most common lymphoid malignancies, in a routine clinical practice. In Table 3, we listed commonly used ancillary testing in lymphoid neoplasms. As the field 
Table 3. Commonly Used Immunophenotypic, Cytogenetic, and Molecular Tests in a Non-Clinical Trial Setting

\begin{tabular}{|c|c|c|c|}
\hline Disease type & Immunophenotyping & Fish studies & Molecular studies \\
\hline CLL/SLL & $\begin{array}{l}\text { Typical phenotype: } \\
\text { Positive for CD20 (dim), CD5, CD23, CD200, } \\
\text { Negative for CD10 }\end{array}$ & $\operatorname{Del}(17 p)$ & $\operatorname{lgVH}$, TP53 \\
\hline $\mathrm{FL}$ & - & $\begin{array}{l}\text { Rearrangements of } \\
\mathrm{BCL2}, \mathrm{BCL6} \text {, and MUM1* }\end{array}$ & - \\
\hline MCL & Cyclin D1, SOX11 Ki67, TP53 & $t(11 ; 14) \dagger$ & TP53 \\
\hline LPL & - & - & MYD88 L265P mutation \\
\hline MM & $\begin{array}{l}\text { Typical phenotype: } \\
\text { Positive for CD138, CD38, CD56, CD117, } \\
\text { Negative for CD19, CD45 }\end{array}$ & $\begin{array}{l}\mathrm{t}(4 ; 14), \mathrm{t}(14 ; 16), \mathrm{t}(14 ; 20) \\
\text { del(17p), add(1p) }\end{array}$ & \\
\hline DLBCL & $\mathrm{CD}_{10}{ }^{\ddagger}, \mathrm{MUM1}^{\ddagger}, \mathrm{BCL} 6^{\ddagger}, \mathrm{BCL} 2, \mathrm{MYC}$ & $\begin{array}{l}\text { Rearrangements of MYC, } \\
B C L 6 \text {, and } B C L 2\end{array}$ & $\begin{array}{l}\text { Cell-of-origin stratification by } \\
\text { GEP }\end{array}$ \\
\hline HGBCL & TdT (to exclude lymphoblastic lymphoma) & $\begin{array}{l}\text { Rearrangements of MYC, } \\
\mathrm{BCL} 6, \mathrm{BCL} 2 \text {; aberrations } \\
\text { of } 11 \mathrm{p} \S\end{array}$ & - \\
\hline
\end{tabular}

$\mathrm{CLL} / \mathrm{SLL}=$ Chronic lymphocytic leukemia/Small lymphocytic lymphoma; $\mathrm{FL}=$ Follicular lymphoma; $\mathrm{MCL}=\mathrm{Mantle}$ cell lymphoma; $\mathrm{LPL}=$ lymphoplasmacytic lymphoma; $\mathrm{MM}=$ Multiple myeloma; $\mathrm{DLBCL}=$ Diffuse large B-cell lymphoma; $\mathrm{HGBCL}=\mathrm{High}$ grade $\mathrm{B}$-cell lymphoma; IgVH=Immunoglobulin heavy chain hypermutation; $\mathrm{GEP}=$ Gene expression profiling. "If pediatric-type FL is in differential diagnosis; + Not necessary if cyclin D1 strongly positive by immunohistochemistry; 'If cell-of-origin stratification by GEP is not available; §If MYC-negative BL is under consideration.

evolves, new tests and panels will be developed, with better prognostic and therapeutic values. Increasingly, pharmaceutical companies and clinician-initiated clinical trials are trying to target a subset of patients based on the results of genetic testing. Whether the results of these clinical trials will rapidly change general clinical practice remains to be seen.

Authors' Contributions: Conception and design: MS, LD and DJ; Acquisition, analysis and interpretation of data: DJ; Drafting the article: DJ; Revising it critically for important intellectual content: MS and LD; Approved final version of the manuscript: MS, LD and DJ.

Conflict of Interest: The authors declare that they have no conflict of interest.

\section{References}

1. Swerdlow SH, Campo E, Harris NL, Jaffe ES, Pileri $\mathrm{SA}$, Stein $\mathrm{H}$, et al, editors. WHO Classification of Tumours of Haematopoietic and Lymphoid Tissues. Revised 4th edition. Lyon, France: International Agency for Research on Cancer (IARC); 2017.
2. Campo E, Ghia P, Montserrat E, Harris NL, Müller-Hermelink HK, Stein H, et al. Chronic lymphocytc leukaemia/small lymphocytic lymphoma: In: Swerdlow SH, Campo E, Harris NL, Jaffe ES, Pileri SA, Stein H, et al, editors. WHO Classification of Tumours of Haematopoietic and Lymphoid Tissues. Revised 4th edition. Lyon, France: International Agency for Research on Cancer (IARC); 2017. p. 216-21.

3. Amaya-Chanaga CI, Rassenti LZ. Biomarkers in chronic lymphocytic leukemia: Clinical applications and prognostic markers. Best Pract Res Clin Haematol. 2016;29(1):79-89.

4. International CLL-IPI working group. An international prognostic index for patients with chronic lymphocytic leukaemia (CLL-IPI): a meta-analysis of individual patient data. Lancet Oncol. 2016;17(6):779-90.

5. Hallek M, Wanders L, Ostwald M, Busch R, Senekowitsch R, Stern S, et al. Serum beta(2)-microglobulin and serum thymidine kinase are independent predictors of progression-free survival in chronic lymphocytic leukemia and immunocytoma. Leuk Lymphoma. 1996;22(5-6):439-47.

6. Robertson LE, Pugh W, O’Brien S, Kantarjian H, Hirsch-Ginsberg C, Cork A, et al. Richter's syndrome: a report on 39 patients. J Clin Oncol. 1993;11(10):1985-9. 
7. Cramer P, Hallek M. Prognostic factors in chronic lymphocytic leukemia-what do we need to know? Nat Rev Clin Oncol. 2011;8(1):38-47.

8. Nabhan C, Raca G, Wang YL. Predicting Prognosis in Chronic Lymphocytic Leukemia in the Contemporary Era. JAMA Oncol. 2015;1(7):965-74.

9. Calin GA, Ferracin M, Cimmino A, Di Leva G, Shimizu M, Wojcik SE, et al. A MicroRNA signature associated with prognosis and progression in chronic lymphocytic leukemia. N Engl J Med. 2005;353(17):1793-801.

10. Döhner H, Stilgenbauer S, Benner A, Leupolt E, Kröber A, Bullinger L, et al. Genomic aberrations and survival in chronic lymphocytic leukemia. N Engl J Med. 2000;343(26):1910-6.

11. Haferlach C, Dicker F, Schnittger S, Kern W, Haferlach T. Comprehensive genetic characterization of CLL: a study on 506 cases analysed with chromosome banding analysis, interphase FISH, $\operatorname{IgV}(\mathrm{H})$ status and immunophenotyping. Leukemia. 2007;21(12):2442-51.

12. Hamblin TJ, Davis Z, Gardiner A, Oscier DG, Stevenson FK. Unmutated Ig $\mathrm{V}(\mathrm{H})$ genes are associated with a more aggressive form of chronic lymphocytic leukemia. Blood. 1999;94(6):1848-54.

13. Stamatopoulos K, Belessi C, Moreno C, Boudjograh M, Guida G, Smilevska T, et al. Over $20 \%$ of patients with chronic lymphocytic leukemia carry stereotyped receptors: Pathogenetic implications and clinical correlations. Blood. 2007;109(1):259-70.

14. Dicker F, Herholz H, Schnittger S, Nakao A, Patten $\mathrm{N}, \mathrm{Wu} \mathrm{L}$, et al. The detection of TP53 mutations in chronic lymphocytic leukemia independently predicts rapid disease progression and is highly correlated with a complex aberrant karyotype. Leukemia. 2009;23(1):117-24.

15. Zenz T, Häbe S, Denzel T, Mohr J, Winkler D, Bühler A, et al. Detailed analysis of p53 pathway defects in fludarabine-refractory chronic lymphocytic leukemia (CLL): dissecting the contribution of 17p deletion, TP53 mutation, p53-p21 dysfunction, and miR34a in a prospective clinical trial. Blood. 2009;114(13):2589-97.

16. Zenz T, Kröber A, Scherer K, Häbe S, Bühler A, Benner A, et al. Monoallelic TP53 inactivation is associated with poor prognosis in chronic lymphocytic leukemia: results from a detailed genetic characterization with long-term follow-up. Blood. 2008;112(8):3322-9.

17. Fabbri G, Khiabanian H, Holmes AB, Wang J, Messina M, Mullighan CG, et al. Genetic lesions associated with chronic lymphocytic leukemia transformation to Richter syndrome. J Exp Med. 2013;210(11):2273-88
18. Nadeu F, Delgado J, Royo C, Baumann T, Stankovic T, Pinyol M, et al. Clinical impact of clonal and subclonal TP53, SF3B1, BIRC3, NOTCH1, and ATM mutations in chronic lymphocytic leukemia. Blood. 2016;127(17):2122-30.

19. Hallek M, Cheson BD, Catovsky D, Caligaris-Cappio F, Dighiero G, Döhner H, et al. iwCLL guidelines for diagnosis, indications for treatment, response assessment, and supportive management of CLL. Blood. 2018;131(25):2745-60.

20. Jaffe ES, Harris NL, Swerdlow SH, Ott G, Nathwani $\mathrm{BN}$, de Jong $\mathrm{D}$ et al. Follicular lymphoma. In: Swerdlow SH, Campo E, Harris NL, Jaffe ES, Pileri SA, Stein $\mathrm{H}$, et al, editors. WHO Classification of Tumours of Haematopoietic and Lymphoid Tissues. Revised 4th edition. Lyon, France: International Agency for Research on Cancer (IARC); 2017. p. 266-77.

21. Federico M, Bellei M, Marcheselli L, Luminari S, Lopez-Guillermo A, Vitolo U, et al. Follicular lymphoma international prognostic index 2: a new prognostic index for follicular lymphoma developed by the international follicular lymphoma prognostic factor project. J Clin Oncol. 2009;27(27):4555-62.

22. Solal-Céligny P, Roy P, Colombat P, White J, Armitage JO, Arranz-Saez R, et al. Follicular lymphoma international prognostic index. Blood. 2004;104(5):1258-65.

23. Louissaint A Jr, Ackerman AM, Dias-Santagata D, Ferry JA, Hochberg EP, Huang MS, et al. Pediatric-type nodal follicular lymphoma: an indolent clonal proliferation in children and adults with high proliferation index and no BCL2 rearrangement. Blood. 2012;120(12):2395-404.

24. Schmidt J, Ramis-Zaldivar JE, Nadeu F, GonzalezFarre B, Navarro A, Egan C, et al. Mutations of MAP2K1 are frequent in pediatric-type follicular lymphoma and result in ERK pathway activation. Blood. 2017;130(3):323-7.

25. Salaverria I, Philipp C, Oschlies I, Kohler CW, Kreuz M, Szczepanowski M, et al. Translocations activating IRF4 identify a subtype of germinal center-derived B-cell lymphoma affecting predominantly children and young adults. Blood. 2011;118(1):139-47.

26. O’Shea D, O’Riain C, Taylor C, Waters R, Carlotti E, Macdougall F, et al. The presence of TP53 mutation at diagnosis of follicular lymphoma identifies a high-risk group of patients with shortened time to disease progression and poorer overall survival. Blood. 2008;112(8):3126-9.

27. Pastore A, Jurinovic V, Kridel R, Hoster E, Staiger AM, Szczepanowski $M$, et al. Integration of gene mutations in risk prognostication for pa- 
tients receivingfirst-line immunochemotherapy for follicular lymphoma: a retrospective analysis of a prospective clinical trial and validation in a population-based registry. Lancet Oncol. 2015;16(9):1111-22.

28. Swerdlow SH, Campo E, Seto M, Müller-Hermenlink HK. Mantle cell lymphoma. In: Swerdlow SH, Campo E, Harris NL, Jaffe ES, Pileri SA, Stein H, et al, editors. WHO Classification of Tumours of Haematopoietic and Lymphoid Tissues. Revised 4th edition. Lyon, France: International Agency for Research on Cancer (IARC); 2017. p. 285-90.

29. Hoster E, Dreyling M, Klapper W, Gisselbrecht C, van Hoof A, Kluin-Nelemans $\mathrm{HC}$, et al. A new prognostic index (MIPI) for patients with advanced-stage mantle cell lymphoma. Blood. 2008;111(2):558-65.

30. Narurkar R, Alkayem M, Liu D. SOX11 is a biomarker for cyclin D1-negative mantle cell lymphoma. Biomark Res. 2016;4:6.

31. Soldini D, Valera A, Solé C, Palomero J, Amador V, Martin-Subero JI, et al. Assessment of SOX11 expression in routine lymphoma tissue sections: characterization of new monoclonal antibodies for diagnosis of mantle cell lymphoma. Am J Surg Pathol. 2014;38(1):86-93.

32. Navarro A, Clot G, Royo C, Jares P, Hadzidimitriou A, Agathangelidis A, et al. Molecular subsets of mantle cell lymphoma defined by the IGHV mutational status and SOX11 expression have distinct biologic and clinical features. Cancer Res. 2012;72(20):5307-16.

33. Nygren L, Baumgartner Wennerholm S, Klimkowska M, Christensson B, Kimby E, et al. Prognostic role of SOX11 in a populationbased cohort of mantle cell lymphoma. Blood. 2012;119(18):4215-23.

34. Orchard J, Garand R, Davis Z, Babbage G, Sahota $S$, Matutes E, et al. A subset of $t(11 ; 14)$ lymphoma with mantle cell features displays mutated $\operatorname{IgVH}$ genes and includes patients with good prognosis, nonnodal disease. Blood. 2003;101(12):4975-81.

35. Hoster E, Rosenwald A, Berger F, Bernd HW, Hartmann S, Loddenkemper C, et al. Prognostic Value of Ki-67 Index, Cytology, and Growth Pattern in Mantle-Cell Lymphoma: Results From Randomized Trials of the European Mantle Cell Lymphoma Network. J Clin Oncol. 2016;34(12):1386-94.

36. Aukema SM, Hoster E, Rosenwald A, Canoni D, Delfau-Larue MH, Rymkiewicz G, et al.

Expression of TP53 is associated with the outcome of MCL independent of MIPI and Ki-67 in trials of the European MCL Network. Blood. 2018;131(4):417-20.
37. Mohanty A, Sandoval N, Das M, Pillai R, Chen $\mathrm{L}$, Chen RW, et al. CCND1 mutations increase protein stability and promote ibrutinib resistance in mantle cell lymphoma. Oncotarget. 2016;7(45):73558-72.

38. Rahal R, Frick M, Romero R, Korn JM, Kridel $\mathrm{R}$, Chan FC, et al. Pharmacological and genomic profiling identifies NF- $\kappa \mathrm{B}$-targeted treatment strategies for mantle cell lymphoma. Nat Med. 2014;20(1):87-92.

39. Swerdlow SH, Cook JR, Cohani AR, Pileri SA, Harris NL, Jaffe ES et al. Lymphoplasmacytic lymphoma. In: Swerdlow SH, Campo E, Harris NL, Jaffe ES, Pileri SA, Stein H, et al, editors. WHO Classification of Tumours of Haematopoietic and Lymphoid Tissues. Revised 4th edition. Lyon, France: International Agency for Research on Cancer (IARC); 2017. p. 232-5.

40. Treon SP, Xu L, Yang G, Zhou Y, Liu X, Cao Y, et al. MYD88 L265P somatic mutation in Waldenström's macroglobulinemia. $N$ Engl J Med. 2012;367(9):826-33.

41. Treon SP, Cao Y, Xu L, Yang G, Liu X, Hunter ZR. Somatic mutations in MYD88 and CXCR4 are determinants of clinical presentation and overall survival in Waldenstrom macroglobulinemia. Blood. 2014;123(18):2791-6.

42. McKenna RW. Jyle RA, Huehl WM, Harris NL, Coupland RW, Fend F. Plasma cell neoplasms. In: Swerdlow SH, Campo E, Harris NL, Jaffe ES, Pileri SA, Stein H, et al, editors. WHO Classification of Tumours of Haematopoietic and Lymphoid Tissues. Revised 4th edition. Lyon, France: International Agency for Research on Cancer (IARC); 2017. p. 241-58.

43. Gonsalves WI, Buadi FK, Ailawadhi S, Bergsagel PL, Chanan Khan AA, Dingli D, et al. Utilization of hematopoietic stem cell transplantation for the treatment of multiple myeloma: a Mayo Stratification of Myeloma and Risk-Adapted Therapy (mSMART) consensus statement. Bone Marrow Transplant. 2018 Jul 9. [Epub ahead of print].

44. Walker BA, Boyle EM, Wardell CP, Murison A, Begum DB, Dahir NM, et al. Mutational Spectrum, Copy Number Changes, and Outcome: Results of a Sequencing Study of Patients With Newly Diagnosed Myeloma. J Clin Oncol. 2015;33(33):391120.

45. Chin M, Sive I, Allen C, Roddie C, Chavda SJ, Smith D, et al. Prevalence and timing of TP53 mutations in del(17p) myeloma and effect on survival. Blood Cancer J. 2017;7(9):e610.

46. Walker BA, Mavrommatis K, Wardell CP, Ashby TC, Bauer M, Davies F, et al. A high-risk, DoubleHit, group of newly diagnosed myeloma identified 
by genomic analysis. Leukemia. 2019;33(1):15970. Epub 2018 Jul 2.

47. Kumar S, Paiva B, Anderson KC, Durie B, Landgren $\mathrm{O}$, Moreau $\mathrm{P}$, et al. International Myeloma Working Group consensus criteria for response and minimal residual disease assessment in multiple myeloma. Lancet Oncol. 2016;17(8):e328-46.

48. Gascoyne RD, Campo E, Jaffe ES, Chan WC, Chan JKC, Rosenwald A et al. Diffuse large B-cell lymphoma, NOS. In: Swerdlow SH, Campo E, Harris NL, Jaffe ES, Pileri SA, Stein $\mathrm{H}$, et al, editors. WHO Classification of Tumours of Haematopoietic and Lymphoid Tissues. Revised 4th edition. Lyon, France: International Agency for Research on Cancer (IARC); 2017. p. 291-7.

49. Alizadeh AA, Eisen MB, Davis RE, Ma C, Lossos IS, Rosenwald A, et al. Distinct types of diffuse large B-cell lymphoma identified by gene expression profiling. Nature. 2000;403(6769):503-11.

50. Rosenwald A, Wright G, Chan WC, Connors JM, Campo E, Fisher RI, et al. The use of molecular profiling to predict survival after chemotherapy for diffuse large-B-cell lymphoma. N Engl J Med. 2002;346(25):1937-47.

51. Hans CP, Weisenburger DD, Greiner TC, Gascoyne RD, Delabie J, Ott G, et al. Confirmation of the molecular classification of diffuse large B-cell lymphoma by immunohistochemistry using a tissue microarray. Blood. 2004;103(1):275-82.

52. Scott DW, Wright GW, Williams PM, Lih CJ, Walsh W, Jaffe ES, et al. Determining cell-oforigin subtypes of diffuse large B-cell lymphoma using gene expression in formalin-fixed paraffinembedded tissue. Blood. 2014;123(8):1214-7.

53. Yamaguchi M, Seto M, Okamoto M, Ichinohasama R, Nakamura N, Yoshino T, et al. De novo CD5+ diffuse large B-cell lymphoma: a clinicopathologic study of 109 patients. Blood. 2002;99(3):815-21.

54. Johnson NA, Slack GW, Savage KJ, Connors JM, Ben-Neriah S, Rogic S, et al. Concurrent expres- sion of MYC and BCL2 in diffuse large B-cell lymphoma treated with rituximab plus cyclophosphamide, doxorubicin, vincristine, and prednisone. J Clin Oncol. 2012;30(28):3452-9.

55. Compagno M, Lim WK, Grunn A, Nandula SV, Brahmachary M, Shen Q, et al. Mutations of multiple genes cause deregulation of NF-kap$\mathrm{paB}$ in diffuse large B-cell lymphoma. Nature. 2009;459(7247):717-21.

56. Leoncini L, Campo E, Stein H, Harris NL, Jaffe ES, Kluin PM. Burkitt lymphoma. In: Swerdlow SH, Campo E, Harris NL, Jaffe ES, Pileri SA, Stein H, et al, editors. WHO Classification of Tumours of Haematopoietic and Lymphoid Tissues. Revised 4th edition. Lyon, France: International Agency for Research on Cancer (IARC); 2017. p. 330-4.

57. Salaverria I, Martin-Guerrero I, Wagener R, Kreuz M, Kohler CW, Richter J, et al. A recurrent 11q aberration pattern characterizes a subset of MYCnegative high-grade B-cell lymphomas resembling Burkitt lymphoma. Blood. 2014;123(8):1187-98.

58. Kluin PM, Harris NL, Stein H, Leoncini L, Campo E, Jaffe ES et al. High-grade B-cell lymphoma. In: Swerdlow SH, Campo E, Harris NL, Jaffe ES, Pileri $\mathrm{SA}$, Stein $\mathrm{H}$, et al, editors. WHO Classification of Tumours of Haematopoietic and Lymphoid Tissues. Revised 4th edition. Lyon, France: International Agency for Research on Cancer (IARC); 2017. p. 335-41.

59. Johnson NA, Savage KJ, Ludkovski O, Ben-Neriah S, Woods R, Steidl C, et al. Lymphomas with concurrent BCL2 and MYC translocations: the critical factors associated with survival. Blood. 2009;114(11):2273-9.

60. Snuderl M, Kolman OK, Chen YB, Hsu JJ, Ackerman AM, Dal Cin P, et al. B-cell lymphomas with concurrent IGH-BCL2 and MYC rearrangements are aggressive neoplasms with clinical and pathologic features distinct from Burkitt lymphoma and diffuse large B-cell lymphoma. Am J Surg Pathol. 2010;34(3):327-40. 